\title{
Population decline and infrastructure: The case of the German water supply system
}

\author{
Diana Hummel and Alexandra Lux*
}

\begin{abstract}
The dynamic interaction between population and water is usually discussed in the context of development issues in Third World countries, but rarely analysed for northern, industrialised countries. Nevertheless, the improvement of a supply system's ability to adapt to demographic changes poses challenges for industrialised countries as well, and generating knowledge for developing adequate solutions also implies new, intriguing tasks for demography. This article analyses the relationships between population decline and water infrastructure using Germany as a case study. After sketching the development of the debate on the correlation between population and problems of water supply, the most relevant demographic factors affecting the water infrastructure are described in general. The authors then identify the implications of demographic change for water demand and use on the one hand, and the resulting effects on technical networks and their economic basis on the other. Finally, approaches for solving the problems and possibilities for taking action are discussed.
\end{abstract}

\section{Introduction}

The relationship between population dynamics and water issues is generally discussed in the context of population growth and water scarcity in developing countries. Often, population growth is perceived to be the demographic factor with strongest impact on water systems (see, for example, Engelmann et al. 2000; Hinrichsen et al. 1998). One can find neo-Malthusian arguments that postulate a direct and causal relationship between high fertility rates, growing numbers of humans and increasing water shortages in arid and semi-arid regions of developing countries. However, the scientific debate has gained greater diversity in recent years by stressing, for example, the relevance of urbanisation and

\footnotetext{
* Diana Hummel (author for correspondence), Institute for Social-Ecological Research (ISOE), Hamburger Allee 45, 60486 Frankfurt, Germany. Email: hummel@isoe.de

Alexandra Lux, Institute for Social-Ecological Research (ISOE), Frankfurt, Germany.
} 
migration. At the same time, many scholars now emphasise that there exists a reciprocal relationship between population and water, i.e., that the relationship between demographic factors and water demand is not unidirectional. Instead, there are numerous mediating factors such as resource management, technology and governance structures that, each in a distinct way, determine the interactions between populations and water in different cultures (Boberg 2005; Meinzen-Dick and Apassamy 2002; Turton and Warner 2002; Sherbinin and Dompka 1998). Despite these changes in the theoretical content of the debate, the regional focus of the issue remains directed towards developing countries in Africa, Asia and Latin America, in which there are, without a doubt, many cases of such acute water and population problems that it becomes a matter of life and death for those who live there.

On the other hand, the discussion surrounding demographic changes in European countries mostly centres on the future security of the social system (pensions, healthcare, welfare) and economic impacts (economic growth and the labour market). Even if there is a growing scientific debate on the issues of natural resources and provision of goods like energy and demographic change, water supply is an emerging issue. Furthermore, the sustainability of a supply system in a certain area is becoming ever more important: Is it socially acceptable, environmentally friendly and economically efficient? Demographic changes in industrialised countries like long-term downtrends in fertility, ageing societies, migration and declining rates of natural population growth have also altered the structure of households and the spatial distribution of the population. In the middle and long-term, demographic changes, especially small-scale spatial distribution and the population's age structure can be regarded as crucial factors not only for the future development of areas such as the social security, health and educational systems, but also as regards infrastructure, transportation systems and supply systems for water, energy or housing. As a result of demographic changes, new forms of complex social-ecological problems are arising, requiring new concepts for regulation and policy options.

Today, demographers and geographers, as well as city planners, are paying increasing attention to overall population decline and especially to the problem of heterogeneous housing trends at the local level in Germany. While the construction of new buildings is essential in prospering regions that are increasing in population, planners are considering the demolition of apartment blocks and the modification of areas for new uses in cities with declining overall population and decreasing population density (Bundesamt für Bauwesen und Raumordnung 2003; Institut für Landes- und Stadtentwicklungsforschung 2003; Lang and Tenz 2003). Thus the simultaneous existence of growing and shrinking populations is evident and is occurring not only on a large scale (East-West), but also at smaller (state, county, city) levels. Infrastructure plays an important role in the process of demolishing and modification of buildings in areas with declining population (Stadtumbau), and it is gradually becoming clear that demographic changes affect 
the local as well as the regional level. So far this phenomenon has been considered primarily with regard to rising financial burdens (Just 2004). Further consequences of demographic shifts for the interrelated systems of drinking water, sewage disposal and energy supply are a relatively new scientific topic and research on this issue targeting Europe or other regions with population decline is scarce and highly dispersed. In Germany, it appears that the possible effects of demographic changes are being increasingly recognised within the current political debate. Despite this realisation, political action remains selectively focused on hot-spot regions mainly in the eastern part of the country.

The remainder of this article provides an analysis of the relations between demographic change and water infrastructure. Demographic data are always crucial for the planning, construction and the establishment of water supply and sewage systems. Besides the demand of industry, business enterprises, municipalities and agriculture it is the amount of people living in a certain area who have to be provided that determines the building design and technical construction of a network-bound infrastructure. Here it is the present effective and future water use per capita as well as the size and distribution of the population in such a supply area which are the most important parameters-both for the technical design and the underlying economic considerations. Thus the topological structure is determined by the knowledge and the assumptions of the planners. Traditionally, this is being done within the framework of the growth paradigm: growth of economy, growth of population and water demand. Shrinking populations and strongly heterogeneous variations in spatial distributions are thus a challenge for infrastructure planning and subsequently for demographic research.

The following assessment of the effects that declining populations have on water supply systems focuses in particular on the economic and technical efficiency of supply as well as on some ecological considerations. First, some peculiarities of the German case are identified and the relevance of the German example for other European regions is discussed. The next section seeks to systematise the most important demographic factors and trends for water supply in 'shrinking regions'. The fourth and main part of the paper deals with the impacts on water use and the management of water supply and sewage disposal systems in Germany. Finally, approaches for solving the problems and possibilities for taking action are discussed.

\section{Demographic problems in Germany and their relevance for other European countries}

In Germany, important demographic driving forces interact in a specific way: fertility rates decline, life expectancy rises and processes of suburbanisation as well as inter-regional migration from East to West continue, generating a situation 
in which the total population is beginning to decline and immigration will be insufficient to compensate the continuing birth deficit. Similar demographic trends can be found in other European regions (Commission of the European Communities 2005). The effect of this phenomenon is the continued ageing and shrinking of the population, even after accounting for significant immigration and increases in life expectancy (United Nations 2000; Lutz and Scherbov 2003). However, the impacts of similar demographic trends for water supply systems are very different in several European countries. The contexts investigated for the German case therefore cannot be simply transferred. First of all, the organisation of a country's water system depends on its political and economic system and such factors as administrative capacity and economic strength. Secondly, and much more importantly, there is Germany's historical peculiarity: In the wake of the reunification of the former GDR and West Germany, unique processes of intrastate migration and an unexpected extreme fertility decline in eastern Germany occurred. Concomitantly, major investment activities in eastern Germany's infrastructure were carried out: pipeline grids, canals and facilities for water supply and sewage disposal were rebuilt very quickly following reunification. This was done under the assumption that eastern German populations would grow and thus increase water demand and use. Unfortunately, the assumption has proved untenable: both the structure and the capacity of the provisioning networks do not coincide with present population size and distribution. As a result, local authorities, administration officials and utility companies currently (approximately fifteen years after reunification) face great challenges in maintaining, restructuring and deconstructing overcapacities in water supply systems. The German case thus has its own specific and rather extraordinary features. Comparable combinations of rapid infrastructure investment and negative population flows cannot be found in any other European country, at least not within the same short time span as they occurred in Germany. Notwithstanding these differences, there are many commonalities and similar demographic trends in Europe that might, in the future, also pose problems for the water supply and sewage disposal systems. Analysis of the German case may thus provide some lessons for other countries and regions.

\section{Demographic factors relevant to water supply and sewage systems}

Certainly there is a wide range of social, political, economic and technical factors with influence on water supply systems. In regions experiencing conditions of population decline, the following demographic factors seem to be particularly relevant:

Population size and changes are fundamentally linked to water use, quantitatively formulated as per-capita use. At first glance, growing populations 
seem to consume more water, while a population decline appears to signify a decreased total demand for drinking water.

Utilities do not provide water to single persons but to private households. It is thus the number as well as the size of households that is relevant for the quantity of water to be supplied as well as for consumption.

By virtue of per-capita changes, the population structure and the age composition have an influence on water supply systems. Roughly speaking, different people with different lifestyles or cultural backgrounds have different wants and requirements for water. Similarly, the elderly have needs and habits quite distinct from those of younger people.

Migration is a relevant impact factor for supply systems because it changes population distribution and population density: It is assumed that the higher the supply density, the larger and more effective will be the water infrastructure.

The first three factors are relevant for the development of water demand and use, while the last factor is of particular importance for the regulation of the water supply and sewage disposal systems. It is assumed that demographic changes have stronger impacts on water consumption in the household sector than on other sectors like industry or agriculture. While demographic developments have their micro-foundation in households, there are only indirect relations to the industrial or agricultural production via demographically influenced changes in consumption, labour supply and the like. But this paper concentrates rather on direct effects than on mediated relationships. Table 1 summarises the relations between demographic trends and water consumption. It distinguishes between effects on individual water demand and effects on total water supply. Nevertheless, if variations in individual behaviour occur in a certain potency (e.g., decreasing household size), there are spill-over effects for the aggregated water supply.

Table 1:

Summarised effects of demographic trends on water consumption

\begin{tabular}{|c|c|}
\hline Demographic trends & Effects on water consumption \\
\hline Decreasing population size & - Reduces amount of total water supply \\
\hline Decreasing household size & $\begin{array}{l}\text { - Increases water demand at household level } \\
\text { because of inefficient water use }\end{array}$ \\
\hline $\begin{array}{l}\text { Increasing number of } \\
\text { households and decreasing } \\
\text { population density }\end{array}$ & $\begin{array}{l}\text { - Increases total water supply in some cases because } \\
\text { additional rinsing of pipelines is necessary in } \\
\text { order to avoid microbial re-contamination of } \\
\text { drinking water due to increased retention time } \\
\text { - Potential loss of economies of scale in water } \\
\text { supply }\end{array}$ \\
\hline $\begin{array}{l}\text { Demographic ageing and } \\
\text { diversification of lifestyles }\end{array}$ & $\begin{array}{l}\text { - Effects depend on the quantitative shifts in age } \\
\text { composition but have not been sufficiently } \\
\text { investigated yet }\end{array}$ \\
\hline
\end{tabular}


As a first result, it can be assumed that demographic factors have an ambiguous impact on water consumption. In the following, we examine these factors in more detail as they relate to present conditions in Germany.

\section{Population size and growth}

It is obvious that changes in the size of a population affect the demand for and the provision of drinking water. As in many other European countries, Germany's demographic situation is characterised by low fertility rates, growing life expectancy and associated shifts in the age distribution. In the past, foreign immigration balanced out the birth deficit. For the future, the forecasts say that immigration will not be sufficient to reverse declining trends. Other attributes of demographic change in Germany are altered household structures (see below), a growing ethnic-cultural heterogeneity as well as changing lifestyles. The Federal Statistical Office estimates that the population will decline by almost ten per cent between 2002 and 2050 to around 75 million (Statistisches Bundesamt 2003a). As a result, there will be fewer people who require drinking water and thus existing infrastructure capacities run the risk of being underutilised. But as illustrated in Table 1, a compensation resulting from further demographic changes might take effect to some extent.

\section{Population structure and age composition}

The fact that there is a connection between the number of people and natural resources seems obvious. However, the relationship between water use and population size is nonlinear because different individuals and populations use water resources in dissimilar ways. In addition to possible changes in water demand and water use due to cultural diversification from international immigration and a pluralisation of lifestyles, population ageing is of major concern throughout Europe. In Germany, the under-twenty age group will decrease by approximately one-third while the number of those over sixty will rise by about one-third. Thus, by 2050, the proportion of under twenty year olds to over sixty year olds will shrink by more than twenty per cent from the 2001 starting level (Statistisches Bundesamt 2003a). In general, significant changes in consumption patterns can be expected as the proportion of elderly people in a society increases. Recent studies on this issue show, that for example the home production of food and other goods increases around retirement age (Miniaci et al. 2002). For water consumption, comparable research still needs to be done. With respect to the household level one can refer to existing micro-data analyses: A study for the western states of the USA indicates that adults use less water than children, but more water than teenagers (Lyman 1992: 2166). By contrast, results from the Netherlands suggest that water demand rises up to the maximum of 149,6 litres per capita and day $(1 / \mathrm{cap} / \mathrm{d})$ for the age group 18-24, but with higher age, it declines to 118,6 1/cap/d for the age group 65 and more (Organisation for 
Economic Co-operation and Development 2002: 44). ${ }^{1}$ Taking the Dutch experiences at the micro-level as an example for Europe it can be assumed that there may be a shift in water demand patterns due to demographic ageing. Generally spoken, effects on water supply depend on shifts in the age composition of the population: Aggregated water supply will fall with demographic ageing as long as the rise in water demand due to growth of the proportion of elderly is exceeded by the decline of water demand due to the decrease of the proportion of young people. With respect to the prognosis of future water supply, not only the change in population size is important but also any changes of the proportion of elderly relative to that of children and teenagers. Quantifying the effects of ratio variations requires detailed knowledge about water use by different age groups; and for the German example this information is lacking.

Furthermore, it has not yet been sufficiently investigated how changes in water use patterns are influenced by an ethnic-cultural heterogeneity resulting inter alia from foreign immigration. A first hint can be obtained from Amsterdam/Netherlands: The city's significant differences in population structure (age and ethnic composition) compared with other areas in the Netherlands are explanatory factors when it comes to residential water consumption above Dutch average (Dalhuisen 2003).

\section{Household numbers and size}

All over Europe (and also worldwide) the number of households is increasing, accompanied by a transition to smaller household sizes. Even in some European countries with negative population growth, the number of households is on the rise. While Europe's population grew by only 5 per cent between 1980 and 1995, the number of households increased by 19 per cent (European Environment Agency 2001). Over the same period, the average household size decreased by 10-15 per cent as a result of lower fertility rates, higher divorce rates, higher percapita income, ageing populations (all of which lead to more single or two-person households) and a decline in multigenerational family units. ${ }^{2}$ In Germany, 37 per cent of all private households consist of one person, the majority of these being among the older age groups. In western Germany, the total population increased by about one-third between 1950 and 2004 to approximately 69 million people. In the same period, the number of private households increased by nearly 80 per cent

\footnotetext{
In detail, the following water consumption figures in litres per capita and day ( $1 / \mathrm{cap} / \mathrm{d})$ are reported for the different age groups: 0-12 years: $113.7 \mathrm{l} / \mathrm{cap} / \mathrm{d}$; $13-17$ years: 137,5 1/cap/d; 18 24 years: 149,6 1/cap/d; 25-34 years: 134,5 l/cap/d; 35-44 years: 125,9 l/cap/d; 45-54 years: 125,1 l/cap/d; 55-64 years: 129,7 1/cap/d; 65 years and older: 118,6 1/cap/d (Organisation for Economic Co-operation and Development 2002).

2 In 1995, the average European household contained 2.5 persons. This is expected to decrease further as the number of one-person households will increase from 30 per cent in 2000 to 36 per cent by 2015 (European Environment Agency 2001). In Norway, more than 40 per cent of the households consist of one person, in Sweden, Finland and Denmark the proportion is over 35 per cent (United Nations Economic Commission for Europe 2003).
} 
to around 32 million, whereas the average household size decreased from 2.99 to 2.12 persons (Statistisches Bundesamt 2005).

It is evident that the decrease in household size will affect the future domestic demand for water, both due to household-related economies of scale and to more effective water-saving household technology (Boberg 2005, Organisation for Economic Co-operation and Development 2002) 3 $^{3}$ Several studies have analysed the role of household size and numbers in relation to natural resources and environmental pressure (MacKellar et al. 1995; Lenzen and Foran 2001; Ewert and Prskawetz 2002; Lui et al. 2003). The growth in the number of households has indirect effects on water supply and quality. In comparison to a household of four persons or more, which benefits economies of scale, households with one to three members consume more water and produce more waste per capita. For Germany it is analysed that the reduction in household size between 1980 and 1990 caused an increase in water demand by 3 litres per day and capita (Björnsen and Roth 1993). An increase in the number of households requires more housing units, increasing the area covered by housing and the materials needed for construction (Bölting 2004). This is often associated with an increase in urban sprawl, which also affects water supply systems (Boberg 2005: 42). In sum, decreasing the household size and increasing the number of households will have a significant impact on future demand for water and its use in the domestic sector. This effect is possibly more significant than the decline or growth of overall population numbers.

\section{Migration, population distribution and density}

Migration and regional population movements, as well as changes in population distribution and settlement patterns, are crucial factors for the structure and organisation of water infrastructure. Most important is the question of how changes in population size and structure will evolve temporally and spatially ${ }^{4}$. In Germany, future demographic changes can be characterised as "regionaldemographic phase shifts" (Schlömer 2004) resulting in different problems for the infrastructure due to distinct points of departure in each region. While the German population at a national level has grown in recent decades because of immigration, the situation at the state and county level is totally different. A study by the Berlin Institute for World Population (Kröhnert et al. 2004) analysed the demographic development of the 440 German counties and cities through 2020.

3 Examples of forms of water use that household-related economies of scale may affect are car washing, laundry, dishwashing, house cleaning or lawn watering. A household consisting of six members will use less than twice the amount of water for these tasks as a three-person household. Water-saving technology investments that lose cost effectiveness with decreases in household size include water saving toilets and showerheads, each of which will cut water consumption twice as much in a six-person household as in a three-person household (Boberg 2005: 42).

4 A relevant comparison of European regions would be interesting; however, this is beyond the scope of this article. 
The results show that post-reunification Germany has experienced a great deal of intra-regional migration.

Herfert (2004) paints a picture of eastern Germany as an entity with a small number of 'islands of stability' surrounded by large areas of heavy population decline. Migration to western Germany varies among regions and is the primary cause of the current trend toward polarisation. Centres like Cottbus or Halle/Saale are losing two per cent of their population annually to westward migration. In these areas, the population is likely to decrease by more than half by the year 2050. Reinforcement of the spatial and regional heterogeneity of growing and declining populations is pivotal for infrastructure systems. In the 1990s, rings of suburbs around large, medium-sized and even small cities still constituted the main pattern of population distribution in eastern Germany that also determined investments in infrastructure (particularly in mains and water processing). Ever since the beginning of the new century, however, those rings have nearly disappeared. The once demographically prosperous rural regions of eastern Germany have now begun a shrinking process because more people are migrating back to the cities or because the small migration gains of the suburban municipalities are easily offset by the death rate. Thus shifts in population distribution are further reasons for an imminent underutilisation of technical infrastructures.

For the next decades this risk may be reinforced due to a rising heterogeneity in demographical developments: The eastern part of Germany is experiencing a process of spatial polarisation and temporal variation. It is assumed that western Germany as well will begin to experience greater regional disparities, and an increasing number of regions will undergo population stagnation or decline over the next two decades. In sum, growth and decline are moving spatially closer together, not only between eastern and western Germany but also within regions and cities (Müller and Siedentop 2004; see also Bucher et al. 2004). This coexistence of different demographic patterns requires advanced methods and tools in water and infrastructure management. Moreover, the process of intra- and inter-regional population diffusion is reversing. Suburbanisation now rarely occurs in eastern Germany, and some metropolitan areas are even facing an inverted trend of migration back to the central cities. Müller and Siedentop (2004: 19f) point out that under conditions of population decline, suburbanisation could lose its importance and be replaced by processes of reurbanisation ${ }^{5}$.

All of these regional, small-scale demographic changes based on population movements are extremely difficult to forecast. While the demographic trends based on fertility and mortality changes as described above have major long-term

There are different reasons for this phenomenon: families with children, who generally prefer quiet neighbourhoods in the suburbs will lose quantitative importance in the coming years. Pensioners, single parents and employed singles will more widely accept inner-city housing. Also, immigration will be one important determinant of population changes in Germany, and the majority of migrants prefers rental housing in city centres. 
effects, migration rather has short-term effects on population size and above all on population distribution and density. Nevertheless, it is precisely the regional and the local level where the network-bound water infrastructure has to be planned, administrated and managed. Against the background of infrastructure longevity (50-100 years) as well as lasting effects of planning and decision-making, those short-term effects are critical for any kind of prognosis of water demand and the subsequent building of technical infrastructure.

\section{Effects of population decline on water supply systems}

The demographic changes in eastern Germany are closely linked to changes in settlement and housing patterns as well as the significant processes of population decline in cities and regions. They also reflect the economic and social consequences of German reunification. The phenomenon of 'shrinking' was already evident soon after the "Wende". In November 2000, the shrinking phenomenon received political and scientific attention mainly through a report of the "Commission on Structural Change in the Housing Market in Eastern German States" by the Federal Ministry of Transport, Building and Housing. This report presented an opportunity to discuss the necessity of urban restructuring, and it became politically expedient to put 'shrinking' on the agenda as a new, consequential path of urban development (Hannemann 2003: 16). Urban development and planning first concentrated on the modernisation of housing stock and new utilisation of vacated areas. In eastern Germany, approximately 1.5 million apartments are currently unoccupied. The demolition of entire residential areas has already begun in many eastern German cities because having apartments remain vacant is financially inefficient (Kil et al. 2003: 25). At the same time, trends in housing and household structures negate the proposition that population decline will lead to a reduction of land use for settlement; along with household size, the total number of households decreases, expectations and needs change and living space per person tends to increase. Additionally, the process of suburbanisation has not slowed down yet. Thus the need for living space will intensify, but with different characteristics than those of today, and the growth of per capita land use along with its infrastructure will continue (Institut für ökologische Raumentwicklung and Institut für Entwicklungsplanung und Strukturforschung 2004; Bölting 2004). In this context, the relevant technical infrastructures are water supply, sewage, energy, district heating or public transport.

One of the major problems is that the shrinkage process endangers the loadcarrying capacity of infrastructures in sparsely populated areas. This has consequences such as an increase in transportation expenditures for the local population. In the future, suburban areas could also be affected. If settlement density declines, critical thresholds of the load-carrying capacity of technical as 
well as social infrastructures and supply facilities (e.g., health care, public transport) will be reached in less densely populated suburban areas earlier than in the cities. Possible consequences of this scenario include longer trips to central facilities and higher fees for technical infrastructures. This might affect elderly people who migrate back to the cities where daily life is easier (Müller and Siedentop 2004).

\subsection{Empirical indications: Non-linear interactions between population dynamics and water supply}

This section provides a more detailed look at the effects of demographic change on network-bound systems of water supply. Since most used drinking water goes to sewage disposal, sewage systems are also obviously affected. The effects of demographic change on water supply become manifest particularly in the eastern states of Germany because many processes come to pass simultaneously. For example, it is empirically evident that population decline as a consequence of a decrease in fertility and the migration of labour will interact with changes in patterns of water consumptions. On the one hand, a reduction in total water demand is caused by a declining number of customers. On the other hand, reduced per capita consumption can be ascribed to changes in household technology (washing machine, dishwasher, etc.) and eco-sensitive consumer behaviour as well as to increasing water prices ${ }^{6}$.

As outlined in chapter 3, changes in population size, household size, population density and demographic ageing processes are the most important demographic dynamics for water consumption at household level and aggregated water supply. In the following, population size is focussed on as an area that is plausible, but rarely investigated in the context of population decline and water use. One reason for the lack of research on this topic might be the complex interaction between declining per-capita consumption and a decline in the number of inhabitants. For the other variables there are some empirical results such as for declining household size (see above). For demographic ageing and changing lifestyles, there is not enough evidence of the structure of consumption patterns. Thus the basis for further analysis is insufficient. The latter indicates desiderata for research about water use by age group or life-style type and more details about the ranges of water use in households and corresponding water amounts, needs dispositions and demand structures. Population density is not considered in the

Empirical evidence of price effects on water demand (price elasticity) is controversial in the international debate (cf. Dalhuisen et al. 2003; Jacobitz 1981). From those discussions it can be concluded that there is no general evidence for price elasticity. There are instances in which higher prices lead to less water consumption, but cases can also be found in which higher prices have no impact on the amount of water consumed. In the case of eastern Germany, price elasticity can be assumed because there was a steep rise in price levels in all eastern German states compared with the pricing modus during the socialist GDR regime. 
following, because the consequences of its changes and related problems do only occur in some places. As stated above, there is a risk of bacterial aftergrowth in drinking water through long retention times of drinking water due to decline of population density and subsequent decline of water demand in a specific service area. But the above-mentioned necessity for additional rinsing of pipelines depends on temperature, the structure of mains as well as water quality parameters. ${ }^{7}$

To use a concrete example, the relationship between population size and water consumption can be illustrated with the official statistical data for the city of Halle/Saale, an urban district, and Saalkreis, a suburban county that is adjacent to Halle/Saale. Both are located in Saxony-Anhalt, a federal state in eastern Germany. These examples were chosen because, although they are physically situated next to each other and are both characterised by birth deficits and economic decline due to deindustrialisation and a subsequent loss in significance (e.g., high unemployment rates, declining GDP), they experience quite different changes in population size and thus a dissimilar evolution of total water demand and per-capita water consumption. At the same time, both are related to suburbanisation processes, the main driver of those disparate development patterns in population size: In the eastern part of Germany, beginning after reunification, building one's own home became possible for many. Supported by state programmes and special tax deductions, a construction boom began and many residents moved from the cities to the peripheries (Oswalt and Rieniets 2006). Against this background of suburbanisation, Saalkreis even gained due to migration from the city Halle/Saale in the last decade; differences in economic structure are minor aspects. Thus Halle/Saale represents the typical development pattern for eastern Germany's cities since the 1990s, while Saalkreis can be seen as an exception for the eastern German case, breaking various trends in demography and water demand. Figures 1 and 2 summarise water demand and total population supplied with water in Halle/Saale and Saalkreis for the period 1991 to $2003 .{ }^{8}$

The bars in Figure 1 show that in Halle/Saale, the population declined by approximately 20 per cent between 1991 and 2003, while water demand (represented by the line) declined by about 60 per cent in the same time period. It is obvious that the latter is nearly constant since 1998 (the aberration in 2001 could be traced back to, inter alia, above-average consumption in summer).

7 In particular for the examples of Halle/Saale and Saalkreis in the following chapter, this measure is not relevant.

8 The figures are based on official water statistics, which aggregate water supply to households and small enterprises. The Federal Association of German Gas and Water Industries (BGW) estimates that about 9 per cent of water supply to this aggregated group goes to small enterprises (BGW 2004). This share is small enough to analyse demographic effects on water consumption, effects of changes in economic structure are negligible. 
Figure 1:

Supplied population and water consumption of households and small enterprises in Halle/Saale

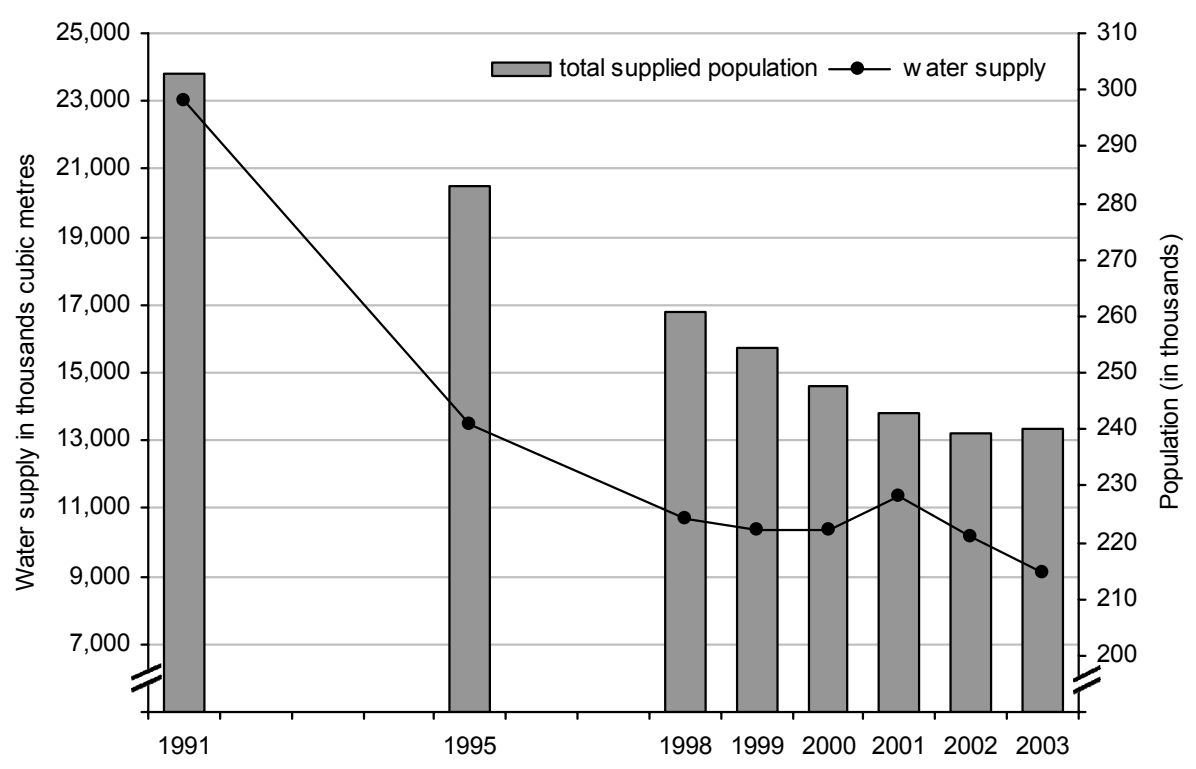

Source: own illustration based on data by State Statistics Office Saxony-Anhalt

Figure 2:

Supplied population and water consumption of households and small enterprises in Saalkreis

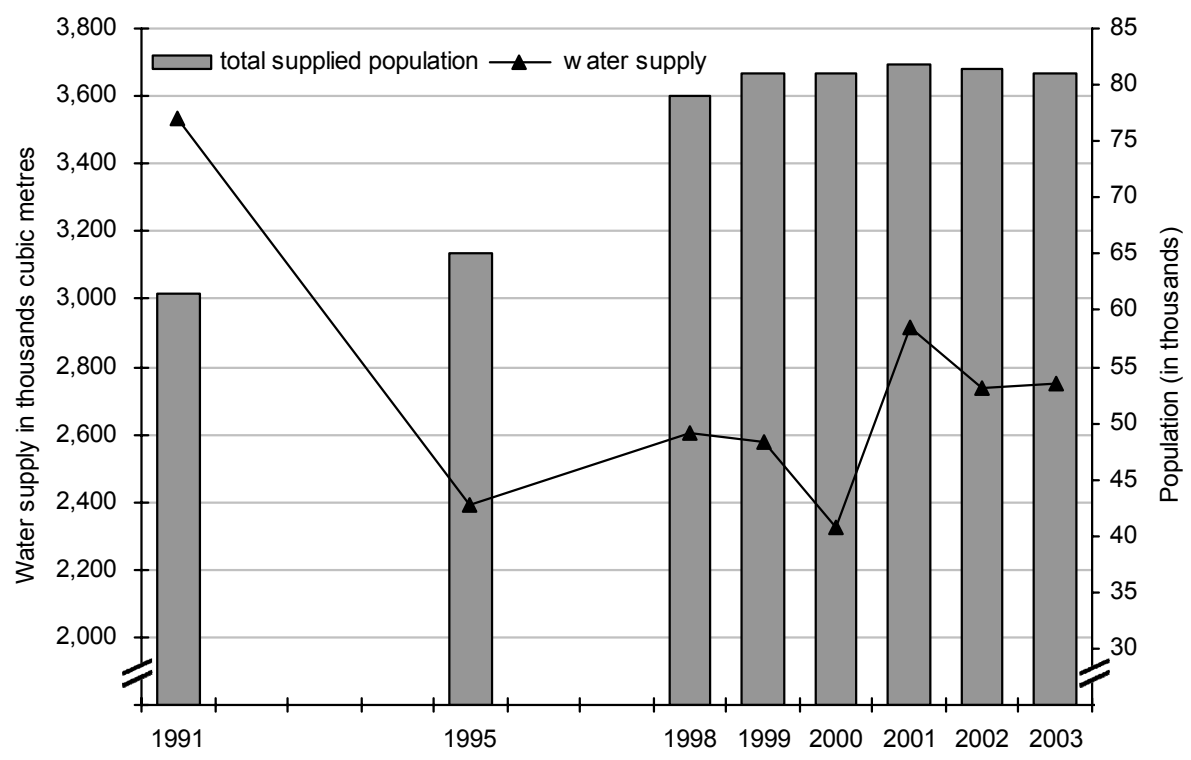

Source: own illustration based on data by State Statistics Office Saxony-Anhalt 
In contrast, Saalkreis (fig. 2) shows a remarkable population growth of about 30 per cent from 1991 to 2003 . Its water consumption declined in the same time period by approximately 20 per cent. The total water consumption declined between 1991 und 1995 around 39 per cent on a lowest value; afterwards it increased notably although the population number remained nearly constant after 1998.

Similarities and differences in changes of per-capita use in Halle/Saale and Saalkreis can be seen in Figure 3. In both cases, the sharpest decrease can be found in the first period, the time after reunification of the two German states, in Halle/Saale on about 42 per cent, in Saalkreis on about 39 per cent. One can conclude that water consumption in 1991 was still highly influenced by certain habits and routines developed during GDR times and that this influence abated in the following years. It is obvious that the total amount in both cases levels off at a nearly constant value since 1998 .

Figure 3:

Per capita consumption in Halle/Saale and Saalkreis

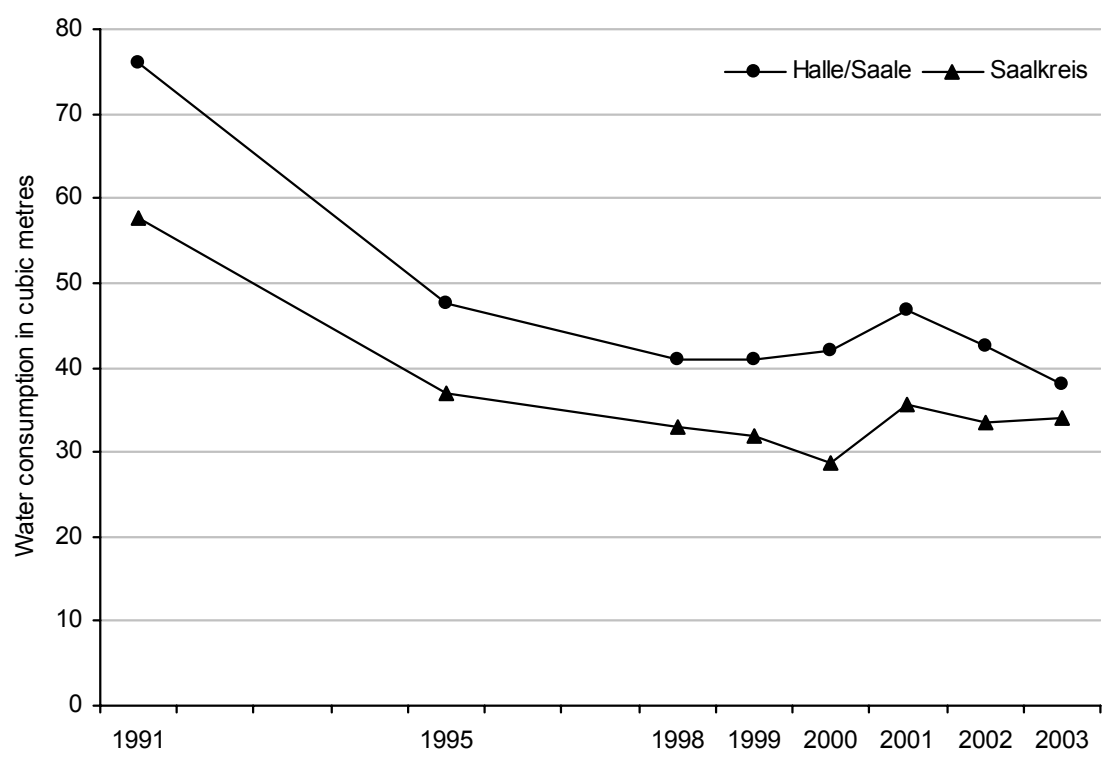

Source: own calculation based on data by State Statistics Office Saxony-Anhalt

But how does demographic change influence water demand? For methodological reasons we make the assumption that consumption patterns stay constant at the level of 1998 for all following years. By controlling for individual consumption patterns in this way, the influence of changes in total population on water consumption can be calculated. In order to draw a more general conclusion, we exclude in our further analysis the period between 1991 and 1995, because 
water consumption in eastern Germany was-as discussed above-highly influenced by political and social transformations.

Assuming constant water consumption patterns includes constant technical equipment in households, constant demand for hygiene, cleaning, cooking, gardening and other purposes of water use, as well as constant general conditions like weather, legal framework, water prices, etc. Fig. 4 and 5 shows the results of this 'thought experiment'. (The continuous line in fig. 4 and 5 corresponds to the line in fig. 1 and 2.) Water demand as stated in official statistics can be compared with an estimation of water demand if only demography influences its progression (the broken line in fig. 4 and 5):

Figure 4:

Real and estimated water demand with assumed constant consumption patterns for Halle/Saale

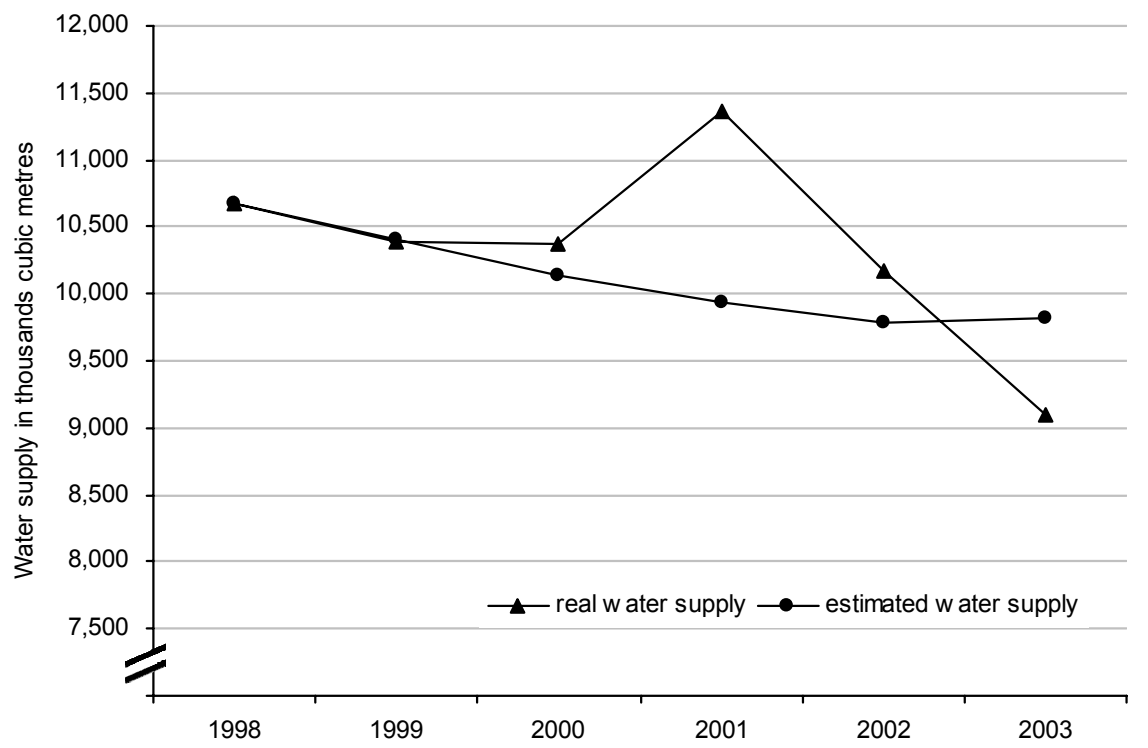

Source: own calculation based on data by State Statistics Office Saxony-Anhalt

Figures 4 and 5 allow an analysis of whether demographic change in population size is a determinant for water consumption. On the one hand, the figures reveal that, in both regions, real and estimated water use/supply do not run parallel. Furthermore the estimated and real values differ widely, especially in Saalkreis. Thus the first conclusion is that population size does have an impact on water demand, but the effect cannot be qualified as linear because the real per capita consumption is not constant. Other factors (summarised above as consumption patterns) incorporate the effects of variations in population size. Given the deviation between the real and the estimated water demand at various points during the selected time period, a second conclusion is that neither the 
effects of population size on water demand nor other effects can be qualified as dominant. There are no unidirectional correlations.

Figure 5:

Real and estimated water demand with assumed constant consumption patterns for Saalkreis

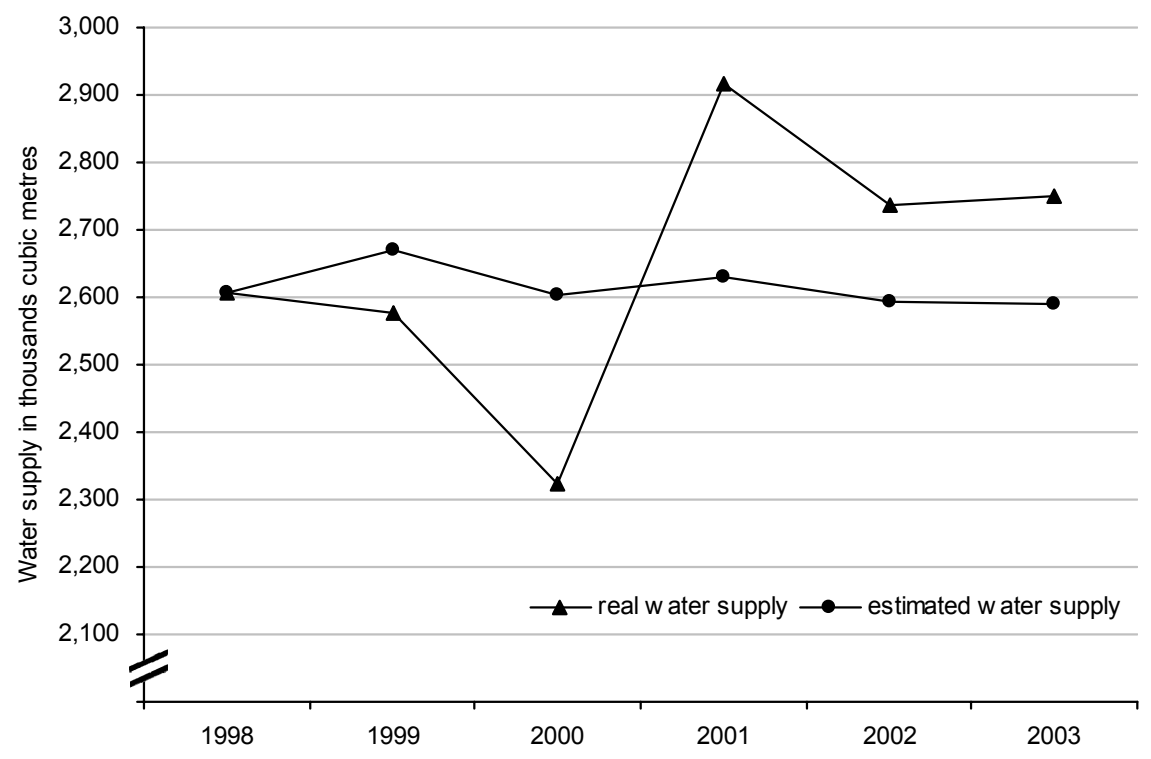

Source: own calculation based on data by State Statistics Office Saxony-Anhalt

The empirical findings presented here rely solely on quantitative shifts in population size and water demand in different supply areas. The various effects of household structure, ageing and changes in needs or lifestyles on water consumption cannot not be identified using existing official statistical data or data from water research. Due to this lack of data, it is difficult to fully understand and analyse the interactions of (declining) population and water consumption, not to mention their inherent complexity. There is clearly a need for further research to gain more insight into these interactions and the ways in which they function. An important indicator for the interactions will be per-capita consumption.

Reciprocal effects (in particular those of shortcomings in water supply such as bad services or insufficient drinking water quality) on demographic dynamics like migration or fertility could not be based on available data and are thus, at the current state of research on demography and water, hard to verify for the present German case. Further, water supply driven effects as reported in the context of the debate on environmental migration (Myers 1997, Biermann 2001) do not seem to be very likely in the case of Germany within the next decades, because of current high standards as well as a strict legislative framework on water supply and management. Nevertheless, with a broader regional focus, especially on the 
central and eastern European countries and their population dynamics, it becomes conceivable that further shortcomings in water supply because of technical and/or economical problems in virtue of declining water demand could be one driver among others for individual decisions to migrate. Further, it is supposed that poor water quality is related to decline of fecundity of women as well as men (Schultz et al. 2003). Further research on these reciprocal effects still needs to be done.

\subsection{Effects on the network: Underutilisation}

As a consequence of heterogeneous change, systems of technical infrastructure already demonstrate restricted functional capacity and related costs. Many sections of the water supply and sewage disposal systems are considerably underutilised due to the joint impact of reduced consumption of drinking water, the drastic drop in industrial water use and the simultaneous population decline. This has grave consequences for the future functional capacity and economic viability of the system. Additionally to demographic shrinkage, drinking water consumption and sewage accumulation in eastern German households decreased by approximately 25 to 30 per cent since 1990, due to increases in prices and fees, as well as improved household technology. In residential areas with vacancy rates of 30 per cent, utilisation of the drinking water and wastewater infrastructure can be more than 50 per cent lower than originally estimated (Koziol 2004).

The decline in the demand for drinking water cannot be technically analysed in the same way as other infrastructure facilities. While social or education infrastructure can be closed down and public transportation can be phased out, solutions such as shutting down or demolishing water supply infrastructure are not available because the remaining population must still be supplied. Whereas in the past the greatest concern was the problem of network overload and the solution lay in extending the network, today many communities face the dilemma of underutilisation. Often, there is a paradox in which underutilisation is accompanied by the need for spatial network extensions to new residential or commercial areas. In eastern Germany these problem dynamics exist in an intensified form, and they can be considered test cases for future developments in western German states such as Saarland or in the area surrounding the Ruhr River. Eastern Germany can perhaps also provide lessons for other European areas that are or will be faced with similar issues of transition.

The notion that population decline necessarily brings a relief in ecological problem areas such as land use, traffic or energy and raw material consumption is short-sighted (cf. Ewert and Prskawetz 2002; Liu et al. 2003). The decrease in drinking water consumption and sewage generation due to population decline and lower demand can entail a number of critical situations for ecology and hygiene (Koziol 2004; Institut für Raumentwicklung and Institut für Entwicklungsplanung und Strukturforschung 2004): 
In the case of drinking water supply, a decrease in consumption and the related diminution of flow quantities can considerably impair the functioning of the supply network. The large diameter of water pipelines can cause the flow of water to slow, leading, in turn, to the creation of stagnation zones, sediment build-up and long delays in water pipes. In this situation the danger of regermination rises, which may call for chlorination and impair the quality of drinking water.

With regard to sewage, decreased flows lead to a build-up of solids in oversized pipes, making frequent flushing necessary. This nullifies any efforts to conserve water.

Anaerobic conversion processes in sewage create odour problems. The deterioration of infrastructure can lead to the corrosion of sewage pipes and tunnels, and increased corrosion can have negative effects for groundwater protection.

The technical and administrative structures of water supply and sewage treatment are far too inflexible to react adequately to declining population numbers and changes in population distribution over the next few years or decades (Lux 2004). Water infrastructure has a lifespan of 50 to sometimes 100 years. The technical infrastructure currently in use serves multiple functions such as water extraction, treatment and distribution and was built to accommodate a growing demand. Therefore, the infrastructure is ill-equipped to respond to short and medium-term changes in water use. This inflexibility raises the danger of technical and economic inefficiency.

\subsection{Economic effects: costs vs. prices}

Reduced demand for water also has economic consequences. Both population decline and changing user behaviour result in price increases associated with ever-constant maintenance costs in many regions. If this occurs, the water supply system may no longer be cost-effective. The economic problem is exacerbated by the fact that at the beginning of the 20th century most of the water supply systems were designed and constructed to accommodate large-scale water consumption and an ongoing industrialisation process. With social and economic change, the industrial share of water consumption has continuously declined over the last several decades. The water supply systems are often oversized for today's and future usage. Due to relative high fixed costs of up to 80 per cent, in a situation of declining overall use, the cost of water per person rises (even if individual consumption remains constant), because the fixed costs are borne by fewer consumers (Kluge et al. 2003; Daiber 2003). Assuming price elasticity for water demand where demand decreases with higher prices, a vicious cycle may be set in motion.

An examination of the price-regulating mechanisms reveals an intensified problem for suppliers because the current price structure does not reflect the cost 
structure in the majority of cases. The water price is determined by both a consumption-independent component (basic price) and a consumption-dependent element (quantity price). On average, the total water price in Germany consists of approximately 12 per cent basic price and approximately 88 per cent quantity price (Daiber 2003). Hence, the price and cost structures do not correspond; 12 per cent basic price cannot cover the 80 per cent fixed costs discussed above.

The reason for such a mismatch can be found in history. This price regime was established under the condition and the assumption of continuous growth of economy, population and water demand. As long as the total costs are covered by in the total price, this calculation works out. This historical development led to the current paradoxical situation in which the basic price is often lower than the fixed cost factor. Fixed costs still exist even when only a small amount of water is used, which, given the present price structure combined with declining water demand, means that it is harder to cover these costs. Such a situation is likely to result in insufficient investment in the system because the financial rationale is missing. The problem for infrastructure planning is that, if the basic price increases due to a further population decline, new social problems will arise. A foreseeable example of such a problem is the affordability and availability of water services in regions with low population density because servicing these areas implies costly long-distance water delivery and sewage disposal.

\section{Improving a supply system's capacity to adapt to demographic changes}

The major challenge for modern planning is to consider long-term as well as short-term developments because of the long life cycles of supply and disposal networks and their high fixed costs. This requires a learning process based on experiences with the technical and economic inability of present systems to deal with the decreasing demand. There are infrastructure problems, particularly in parts of eastern Germany, that are difficult to resolve because the structures and facilities were designed for the long term. In many of these regions it was not until the 1990s that installations were renewed according to traditional western German techniques and traditional eastern German growth thinking, causing the depreciation and amortisation times to remain long.

\section{Innovative technical approaches}

Despite these obstacles in dealing with old infrastructure, there is still an opportunity to actively respond to future developments and to develop alternative ways to supply basic services. City planning should be evaluated from an engineering viewpoint, preferably utilising existing infrastructure networks. If the existing infrastructure is underutilised, there should be no new structural developments outside the current network. In addition, decentralised solutions 
should be made possible (Koziol 2004: 82f.). For example, at the technical level of the water supply system, this may mean modular construction of installations and pipes. When smaller units are connected together to form flexible networks, it is relatively easy to shut off or add system elements. Moreover, a smaller, more decentralised technical infrastructure (installations for rain-water collection and use, plant-based water treatment facilities, etc.) or a combination of coordinated and interconnected central and decentral installations may reduce the financial risks of long-term infrastructure construction. The technical aspects of infrastructure also have effects on the economic foundations. Technical flexibility raises the possibility of a new interpretation of investment sums, profit-return and write-off times, credit bases and eventually also fixed-cost structures. Economist T. Just (2004: 18) concludes, "If municipalities want to make themselves 'demography-proof' with sweeping urban conversion programmes, they must have regard for more than just housing and/or architectural concerns. In parallel, they will also need to identify the optimal size of their grid infrastructure".

\section{Dealing with uncertainty}

In fact, establishing the 'optimal size' is anything but trivial. The political and planning challenge is, above all, to appropriately alter the supply systems in order to accommodate demographically induced changes on the demand side. Today, the problem is that past decisions, especially in the area of material infrastructure, are difficult to rectify in the short or even medium term. This situation relates to the fundamental dilemma of ascertaining the framework for planning decisions. At the beginning of the 1980s, the German government estimated the average national water demand to be 219 litres per person per day (Umweltbundesamt 1982). In 2001, the value lay at barely 127 litres, demonstrating that the tendency is downward (Statistisches Bundesamt 2003b). This example does not imply errors in the demand forecast but rather demonstrates the uncertainties in the context for decision-making in the planning process, especially if those decisions are geared toward the long term. Unexpected developments such as technological change and modifications in usage patterns as well as climate factors cause insecurity that make precise water demand forecasts, even for the next twenty years, impossible. A central demographic issue in this equation is that natural population growth can only change over the course of several generations and therefore shows relatively little reaction to any political impulses. However, aggregate demographic data alone are not sufficient for planning of water supply systems and other infrastructure. In this case, intra-regional migration and the related strengthening of demographic heterogeneity are the deciding factors. Studies with a regionally specific focus and models that integrate migration are of particular value. In the context of the forecasting problem (see Lutz et al. 2004), the connection between demographic changes and supply systems means that the future flexibility and the limited reversibility of planning decisions must also be taken into account. Rather than creating fixed and rigid long-term conditions, 
decisions must be flexible, and oriented toward specific demands. Therefore these decisions should be reversible to a certain degree in order to facilitate future modifications. Such a planning requires giving up the idea of huge and uniform, supra-regional areas of supply. Instead, smaller facilities that can be connected are required.

\section{Ascertaining the basis for planning decisions}

It seems paradoxical that when economic foundations are made more sound in the short term, it is easier to make infrastructural adjustments and adaptations to new conditions in the long term. A pivotal point for regulation is the definition of goals for supplying the population. These goals should be consistent with other development strategies. Indeed, the formulation of the content of the goals itself is important. Do planners need to resolve how to supply a population of size $X$ with water quantity $\mathrm{W}$ that increases $\mathrm{Z}$ per cent annually until year $\mathrm{T}$ ? Or should they pursue the alternative goal of establishing a sustainable, i.e., socially acceptable, environmentally friendly and economically plausible supply system in a certain area, given that population size and water demand will remain within a certain range? In the latter goal formulation, no strict quantitative targets are initially set, and the possibility of finding alternative methods for achieving goals along a more sustainable development path remains open (Lux 2004). Generating scenarios can illustrate the (im-)possible and alternative development directions along the edges of a 'sustainability corridor'. As a basis for planning, there is a development path that opens distinct options and makes it possible to consider the different stages of progress toward a goal (e.g., the population fluctuation along a certain path).

\section{Conclusion and Outlook}

The demographic trends in Germany indicate complex interactions between population changes and transformations of infrastructure and supply systems. On the one hand, existing supply systems can cause demographic changes by acting as 'attractors', offering incentives to entice certain groups to migrate into the region. Furthermore, water quality can affect health and mortality. As described above, demographic changes have significant impacts on supply systems and infrastructure. The functional capacity of these systems requires a certain population size and density. If population size and composition change considerably, there might be adverse economic, social and technological effects on the supply systems.

Until recently, utilities have been thought of only in terms of growth in regional and urban planning. Under the current and expected future demographic development, these growth-oriented plans need to be critically scrutinised. However, it is not enough to simply substitute the assumptions of growth with a 
shrinking paradigm. With respect to water supply systems, demographic growth and shrinkage processes must be regarded as occurring simultaneously; temporal as well as spatial effects have to be considered, along with quantitative and qualitative aspects of demographic changes. Utilities need strong, spatially differentiated data for estimating demographic changes in local and regional water supply areas. Therefore, changes of the population size and structure are relevant, as well as intra-regional migrations.

With a mind to sustaining the adaptive capacity of supply systems and finding solutions for the problems, a greater differentiation between pressures, states and responses is required and thus an enhanced knowledge of the interlinkages between population change and supply. Numerous questions still remain to be answered with respect to the impacts of 'shrinking populations' on natural resource-based supply systems, For example, with respect to changing demand and use, do elderly people need more or less water on average? Does the water demand related to medical and geriatric care change as a result of a larger share of elderly people? What is the structure of water demand and use by people with different lifestyles in a multi-cultural society? Does declining water demand lead to worse water quality, resulting in effects on health and mortality? Are elderly or other vulnerable groups notably affected? With respect to the organisation of supply systems, particularly the problem of prognostic uncertainty, how can planners and decision-makers deal with unexpected demographic events such as unforeseen migratory processes? How can the supply systems adapt to the delayed effects of demographic changes? Are there common issues in other European countries, what are the differences?

The issue of population decline is a very new field for various disciplines, especially urban and regional planning, engineering and economics, but also public health and medicine or political science. As a result, it seems to be an ideal field for transdisciplinary research and cooperation between demographic research and other disciplines.

\section{Acknowledgements}

We would like to thank Egon Becker, Institute for Social-Ecological Research (ISOE) Frankfurt/Germany, and the members of the junior research group "Demographic trends, needs and supply systems (demons)" as well as two anonymous referees for their valuable comments and important contributions to improve the paper. Any errors are the responsibility of the authors. The research reported in this paper was in part financially supported by the Federal Ministry for Education and Research, Germany (grant no. 07NGS04). 


\section{References}

Biermann, F. 2001. "Umweltflüchtlinge. Ursachen und Lösungsansätze." Aus Politik und Zeitgeschichte B12/2001: 24-29.

BGW. 2004. 116. Wasserstatistik. Bundesrepublik Deutschland. Bonn: Wirtschafts- und Verlagsgesellschaft Gas und Wasser.

Björnsen, G. and U. Roth. 1993. "Einfluß der Haushaltsgröße auf den Wasserbedarf." Wasser und Boden 45(3): 155-158.

Bundesamt für Bauwesen und Raumordnung. 2003. Stadtumbau West: Programm und Pilotstädte: Forschungsfeld im Forschungsprogramm Experimenteller Wohnungsund Städtebau (ExWoSt). Berlin/Oldenburg: BBR.

Boberg, J. 2005. Liquid Assets. How Demographic Changes and Water Management Policies Affect Freshwater Resources. Santa Monica: RAND.

Bölting, H. 2004. "Wohnen neu erfinden?" In: Ministerium für Städtebau und Wohnen, Kultur und Sport des Landes Nordrhein-Westfalen (ed.) Stadtumbau West. Intelligentes Schrumpfen. Düsseldorf, pp. 118-127.

Bucher, H., C. Schlömer, and G. Lackmann. 2004. "Die Bevölkerungsentwicklung in den Kreisen der Bundesrepublik Deutschland zwischen 1990 und 2020.” Informationen zur Raumentwicklung. Raumordnungsprognose 2020 3/4, 107-126.

Commission of the European Communities. 2005. Confronting demographic change: a new solidarity between the generations. Green Paper. COM (2005) 94 final, 16.3.2005. Brussels: Commission of the European Communities

Daiber, H. 2003. "Höhere Grundpreise - was sagen Gebühren- und Kartellrecht." In: Rationalisierungsmaßnahmen in der Wasserversorgung. Umsetzungsstatus und künftige Entwicklungen. WAR-Schriftenreihe 151. Darmstadt, TU Darmstadt, pp. 1728.

Dalhuisen, J. M. 2003. "The Netherlands.” In: S. Mohajeri, B. Knothe, D.-N. Lamothe, and J.-A. Faby. Aqualibrium. European Water Management between Regulation and Competition. Brussels, European Commission, pp. 217-223.

Dalhuisen, J. M., R. Florax, H. de Groot, and P. Nijkamp. 2003. "Price and Income Elasticities of Residential Water Demand: A Meta-Analysis." Land Economics 79(2): 292-308.

European Environment Agency. 2001. "Information for improving Europe's environment. Indicator Household number and size." Accessed 15 September 2006 at «http://themes.eea.eu.int/Sectors_and_activities/households/indicators/consumption?p rintable=yes»)

Engelmann, R. and P. LeRoy. 2000. Mensch, Wasser! Report über die Entwicklung der Bevölkerung und die Zukunft der Wasservorräte. Second edition. Hannover: Balance.

Ewert, U. and A. Prskawetz. 2002. "Can Regional Variations in Demographic Structure Explain Regional Differences in Car Use? A Case Study in Austria." Population and Environment 23(3): 315-345.

Hannemann, C. 2003. "Schrumpfende Städte in Ostdeutschland - Ursachen und Folgen einer Stadtentwicklung ohne Wirtschaftswachstum." Aus Politik und Zeitgeschichte B 28/2003: 16-23.

Herfert, G. 2004. Regionale Differenzierung der demographischen Entwicklung in den neuen Ländern 2000-2002. Leipzig: Leibnitz-Institut für Länderkunde. 
Hinrichsen, D., R. Bryant, and U. D. Upadhyay. 1998. "Solutions for a Water-Short World." Population Reports Series M, No. 14. Accessed 15 September 2006 at «http://www.infoforhealth.org/pr/m14edsum.shtml»

Institut für Landes- und Stadtentwicklungsforschung des Landes Nordrhein-Westfalen (ed.) 2003. "Aspekte der demographischen Entwicklung in NRW." Dokumentation des Workshops am 11 Oktober 2002 in Dortmund. Dortmund: ILS

Institut für ökologische Raumentwicklung/Institut für Entwicklungsplanung und Strukturforschung. 2004. "Demographischer Wandel - Herausforderung für eine ökologische Siedlungsentwicklung. Marienthaler Erklärung. Ein Aufruf zur Diskussion.” Dresden/Hannover. Accessed 15 September 2006 at «http://www.tudresden.de/ioer/PDF/Presse/marienthaler_erklaerung.pdf\#search $=\% 22$ marienthaler $\%$ 20erklärung\%22»

Jacobitz, K., J. Klaus, J., B. Michel, and I. Cornelius. 1981. Preiselastizität des häuslichen und gewerblichen Wasserverbrauchs und Abwasseranfalls. Darmstadt: Cooperative Infrastruktur + Umwelt.

Just, T. 2004. "Demographic developments will not spare the public infrastructure." Current Issues - Demography Special. June 2004. Frankfurt: Deutsche Bank Research.

Kil, W., M. Doehler, and M. Bräuer. 2003. "Zukunft der Städte und Stadtquartiere Ostdeutschlands." Aus Politik und Zeitgeschichte B 28/2003: 25-31.

Kluge, T., M. Koziol, A. Lux, E. Schramm, and A. Veit. 2003. "Netzgebundene Infrastrukturen unter Veränderungsdruck - Sektoranalyse Wasser." netWORKSPapers No. 2, Berlin: Deutsches Institut für Urbanistik.

Koziol, M. 2004. "The Consequences of Demographic Change for Municipal Infrastructure." German Journal of Urban Studies 44(1). Accessed 15 September 2006 at «http://www.difu.de/publikationen/dfk/en/04_1/04_1_koziol.shtml»

Kröhnert, S., N. van Olst, and R. Klingholz. 2004. Deutschland 2020. Die demographische Zukunft der Nation. Berlin: Berlin-Institut für Weltbevölkerung und globale Entwicklung.

Lang, T. and E. Tenz. 2003. Von der schrumpfenden Stadt zur Lean City. Prozesse und Auswirkungen der Stadtschrumpfung in Ostdeutschland und deren Bewältigung. Dortmund: Dortmunder Vertrieb für Bau- und Planungsliteratur

Lenzen, M. and B. Foran 2001. "An input-output analysis of Australian water usage." Water Policy 3(4): 321-340.

Liu, J., G. C. Daily, P. R. Ehrlich, and G. W. Luck. 2003. "Effects of household dynamics on resource consumption and biodiversity." Nature 421: 530-533.

Lutz, W. and S. Scherbov. 2003. "Future Demographic Change in Europe: The Contribution of Migration." Interim Report IR-03-066. Laxenburg, IIASA

Lutz, W., W.C. Sanderson, and S. Scherbov, S. (eds.) 2004. The End of Population Growth in the 21st Century. New Challenges for Human Capital Formation \& Sustainable Development. London and Sterling: Earthscan.

Lux, A. 2004. "Sechs Thesen zur Bedeutung richtiger Weichenstellungen in Planungsprozessen." In: Landeszentrale für Umweltbildung Rheinland-Pfalz (ed.) Geisterdörfer im Hunsrück. Mainz: LZU.

Lyman, R. A. 1992. "Peak and Off-Peak Residential Water Demand" Water Resources Research 28(9): 2159-2167.

MacKellar, F. L., W. Lutz, C. Prinz, and A. Goujon. 1995. "Population, Households, and CO2 Emissions.” Population and Development Review 21(4): 849-865. 
Meinzen-Dick, R. and P. P. Appasamy. 2002. "Urbanization and Intersectoral Competition for Water," In: Woodrow Wilson International Center for Scholars Environmental Change and Security Project (ed.) Finding the Source: The Linkages Between Population and Water. Washington, D.C., The Woodrow Wilson Institute, pp. 27-51.

Miniaci, R., C. Monfardini, and G. Weber. 2002. "Changing Consumption Patterns." In: H. Siebert (ed.) Economic Policy for Aging Societies. Berlin/Heidelberg, Springer.

Müller, B. and S. Siedentrop. 2004. "Growth and Shrinkage in Germany-Trends, Perspectives and Challenges for Spatial Planning and Development." German Journal of Urban Studies 44(1). Accessed 15 September 2006 at «http://www.difu.de/publikationen/dfk/en/04_1/04_1_mueller_siedentop.shtml»

Myers, N. 1997. "Environmental Refugees." Population and Environment 19(2): 167-182

Oswalt, P. and T. Rieniets. 2006. Atlas of Shrinking Cities. Ostfildern: Hatje Cantz.

Organisation for Economic Co-operation and Development. 2002. Household Energy \& Water Consumption and Waste Generation: Trends, Environmental Impacts and Policy Responses. Sector case studies series. Accessed 15 September 2006 at «http://www.olis.oecd.org/olis/2001doc.nsf/LinkTo/env-epoc-wpnep(2001)15-final»

Schlömer, C. 2004. "Die privaten Haushalte in den Regionen der Bundesrepublik Deutschland zwischen 1990 und 2020." Informationen zur Raumentwicklung. Raumordnungsprognose 2020 3/4: 127-150.

Schultz, I., D. Hummel, C. Empacher, T. Kluge, A. Lux, E. Schramm, S. Schubert, and I. Stiess. (2003). Research on gender, the environment and sustainable development. Luxembourg, Office for Official Publications of the European Communities.

Sherbinin, A. and V. Dompka (eds.) 1998. Water and Population Dynamics: Case Studies and Policy Implications. Washington, D.C., American Association for the Advancement of Science.

Statistisches Bundesamt. 2003a. Bevölkerung Deutschlands bis 2050. 10. koordinierte Bevölkerungsvorausberechnung. Wiesbaden: Statistisches Bundesamt.

Statistisches Bundesamt. 2003b. Statistisches Jahrbuch 2003 für die Bundesrepublik Deutschland. Wiesbaden: Statistisches Bundesamt.

Statistisches Bundesamt. 2005. Leben und Arbeiten in Deutschland - Ergebnisse des Mikrozensus 2004. Wiesbaden: Statistisches Bundesamt.

Turton, A.R. and J.F. Warner. 2002. "Exploring the Population/Water Resources Nexus in the Developing World." In: Woodrow Wilson International Center for Scholars Environmental Change and Security Project (ed.) Finding the Source: The Linkages Between Population and Water. Washington, D.C., The Woodrow Wilson Institute, pp. 52-81.

Umweltbundesamt. 1982. Waserversorgungsbericht. Bericht über die Wasserversorgung in der Bundesrepublik Deutschland. Bericht des Bundesministers des Innern, erarbeitet und abgestimmt mit den in der Landesarbeitsgemeinschaft Wasser zusammengeschlossenen obersten Wasserbehörden der Länder. Berlin: UBA

United Nations Economic Commission for Europe. 2003. Trends in Europe and North America. The Statistical Yearbook of the Economic Commission for Europe 2003. Accessed 15 September 2006 at «http://www.unece.org/stats/trend/ch2.htm»

United Nations. 2000. Replacement Migration: Is it a solution to declining and ageing populations? New York: UN. 